\title{
Discussions on Heterogeneous Barrier of British and American Literature and Cultivation of Cross-cultural Awareness of College Students
}

\author{
Jing Liang \\ College of Foreign Languages and Literature, Wuhan Donghu University, Wuhan \\ Hubei ,430200,China
}

Key words: Heterogeneous barrier, Cross-cultural awareness, British and American literature, College student, Cultivation, Emotion, Behavior.

\begin{abstract}
Chinese colleges and universities are actively carrying out British and American literature education to enhance students' cross-cultural awareness, foster international talents, and help students to exert their value better after they enter society. From the aspect of cross-cultural awareness cultivation, however, the most important problem is how to overcome the heterogeneous barrier of British and American literature. About this problem, this paper aims to discuss the dialectical unification relation between British and American literature and Western culture system and the meaning of overcoming the heterogeneous barrier of British and American literature, and analyze the measures for cultivating cross-cultural awareness of college students from the aspects of emotion system and behavior system.
\end{abstract}

\section{Introduction}

Cross-cultural awareness refers to that foreign language learners have outstanding knowledge and adaptive capacity of target culture, which are reflected in cross-cultural communication in the form of standard speech comprehension and communication consciousness based on target language culture. It was proposed in the English Teaching Syllabus for English Majors of Colleges and Universities that the curriculum of British and American literature aims to teach students to develop certain literary criticism consciousness, and enhance the ability of reading and comprehending British and American literature, which is the embodiment of cross-cultural awareness.

\section{Demonstration of Dialectical Unification Relation between British and American Literature and Western Culture}

In essence, the dialectical unification relation between literature and culture is reflected in two aspects. On one hand, literature should be an important carrier of culture; on the other hand, culture is the objective base of literature. Culture is spiritual wealth created under the ideological environment, while literature is concrete ideology, which is presented in the social, economic and ecological culture system in the form of language and words, and an important tool of cultural transmission and inheritance. Thus, literature is an important content presentation and the main manifestation of culture.

An apparent advantage of British and American literature education of colleges and universities is to cultivate students' cross-cultural awareness. Chinese culture is significantly different from Western culture, which reflect different political systems, economic levels and social ideologies. British and American literatures were created to present details of Western culture, and influenced by the development track of Western realistic society, forming a dialectical unification relation between culture and literature. Thus, students are required to master Western culture knowledge, and British and American cultural tradition, historical tradition and thinking habit to a certain extent, so that they can truly comprehend the cultural thoughts conveyed in British and American literature, and learn British and American literature well[1]. 


\section{Significance of Cross-cultural Awareness Cultivation to Overcoming Heterogeneous Barrier of British and American Literature}

The cultivation of cross-cultural awareness of college students aims to help them to overcome heterogeneous barrier of British and American literature, understand better about the cultural awareness and connotation reflected in British and American literature, and accumulate international cultural literacy. Thus, it is held in this paper that the cultivation of cross-culture awareness of college students in British and American literature teaching should be conducted to achieve two aims, namely overcoming heterogeneous barrier of language and overcoming heterogeneous barrier of language culture.

\section{1 (I) Analysis on Overcoming Heterogeneous Barrier of Language}

The heterogeneity between Western literary language and Chinese literary language is prominent, so we must overcome the heterogeneity with the help of literary language translation to harmoniously integrating Chinese culture and Western culture.

From the perspective of language family, Chinese and English belong to different language families, and significantly different from each other in respect of grammar. The literary heterogeneous barrier will become more prominent in translation of classical Chinese literature works because such translation involves a large quantity of intralingual translation. Besides, there is a large ideological understanding gap between Chinese literature and British and American literature, which largely increases the difficulty of translation. On this point, famous British translator George Steiner pointed out that "intralingual translation is the most important link of interlingual translation, because literary language is of temporality, and all cultural history contents contained in works must be fully considered and accurately mastered in the process of wording and phrasing.” This comment shows that understanding Chinese and Western literatury languages is the key to overcoming heterogeneous barrier between Chinese literary language and Western literary language.

Besides, that it is impossible to determine a counterpart in the target language of that in the source language and that every author has his own literary language style also are typical heterogeneous barriers. Considering the important influence and effect of literary language on cultural development in the process of modern cultural exchange, it is necessary to research and overcome the heterogeneous barriers of British and American literature. Take the example of the words of "democracy" and "science". There were no counterpart of the two words in traditional Chinese vocabulary. The two words were gradually recognized and introduced into China through translating Western literature works, their counterparts in Chinese were finally determined and became important Chinese words. At that time, "democracy" and "science" were transliterated by Chen Duxiu into “德先生 (Mr. D)” and “赛先生 (Mr. S)”. The outcome of transliteration sounds strange, and is limited to use. Transliteration is hardly accepted. Thus, as culture evolved, the counterparts of “民主” and “科学” were finally determined. Actually, heterogeneous barriers of literary language only reflect one aspect of language heterogeneity between Chinese culture and Western culture. We should discuss and overcome heterogeneity between Chinese literature and Western literature from other aspects, such as heterogeneous barriers of literary language.

\section{2 (II) Analysis on Overcoming Heterogeneous Barrier of Language Culture}

The exchange of Chinese and Western cultures is reflected in not only literary language, but also in heterogeneous culture exchange. Literary language, as an important carrier of cultural transmission, is closely linked with both Chinese and Western cultures. It is because of the heterogeneous barriers based on language culture that the exchange study between Chinese language culture and Western language culture is restricted, so people have been hoping to overcome the heterogeneous barriers to break the restriction to create an ideal state that various language cultures in the world are equal. It is held in this paper that the British and American literature teaching of colleges and universities is in a dilemma. If the heterogeneous content of language culture is excessively emphasized in teaching, the quality of normal heterogeneous culture exchange will be affected. Hence, in teaching process, 
teachers must relatively balance the heterogeneity of British and American literature and the identity between Chinese and Western literary language cultures, which is the research focus of literary creation and translation at present. The reason why the translated works of British and American literature of some litterateurs are popular is that their translation conforms to the characteristics of Chinese language and literature. They have retained the original taste and flavor of British and American literature, and covered the heterogeneity between Chinese and Western cultures to the largest extent. For example, Lin Shu translated the Merchant of Venice into “一磅肉 (a pound of flesh)". The title shows that he fully considered the characteristics of the audiences of Chinese literature language, and integrated into humanistic ideas. Meanwhile, he also realized that nanthroponym, toponym and object name were commonly used in title of British and American literature books, such as “三国志” (one of the four great Chinese classical novels) which was translated into The Three Kingdoms; while Chinese litterateurs tended to condense story line in the title, to reflect the core idea of a literary story. This is the language culture heterogeneity between British and American literature and Chinese literature. On the contrary, the English word of “milkway” (银河 in Chinse) should not be translated into “牛奶路”, which helps reduce the confusion about British and American articles, and promotes cultural exchange and culture language learning process. Chinese colleges and universities also should strive to promote Chinese and Western culture exchange with an attitude of equally treating and respecting both Chinese and Western literatures and literary languages. Only in this way, international talents cultivation can be truly realized, to achieve exchange of culture between Chinese and Western[2].

\section{Strategy of Cross-cultural Awareness Cultivation of College Students}

The aims of cultural awareness cultivation of college students are: to overcome the heterogeneous barriers of British and American literature, and to make them form correct values and learn to properly treat the heterogeneity between British and American culture and Chinese culture. In a word, we should establish a emotion system and a behavior system of cross-culture awareness education for them, and make teaching strategy based on the two systems.

\section{1 (I) Establishment of Emotion System of Cross-culture Awareness of College Students}

To help college students to overcome heterogeneous barriers of British and American literature, we should cultivate the emotion system of students in university education, which will be helpful for them to improve their tolerability, flexibility and empathy ability in the aspect of communicative ability, to truly realize an open-type British and American literature cross-culture teaching mode focusing on appreciation.

In the process of learning British and American literary language, we should get clear about the purpose of exchanging and integrating Chinese and Western cultures and language cultures. Considering that college students developed their Chinese culture background early, teachers should strive to transfer their culture background into the English language culture environment to help them develop bilingual competence. Hence, teachers should learn about the heterogeneity between the two cultures, create a "culture language atmosphere" in classroom, focus on the training of reading and writing abilities of students, enrich the teaching contents of objective language culture background and the heterogeneity of communication environment, and help students to change their way of language and culture learning, to prevent students from getting embarrassed in the process of learning British and American culture and language.

The British and American literature learning method based on emotion system mentioned herein is positive transfer. The purpose of adopting this method is to get rid of negative transfer in students' learning process. According to behavioristic psychology, chronic negative language transfer will occur to learners when they learn heterogeneous cultures, which makes them often make mistakes in language learning, and causes language learning disability. That positive transfer is adopted in British and American literature teaching in colleges and universities is to eliminate the interference caused 
by such heterogeneous culture difference and the subjectivity of cultural criteria and values in English learning, and to judge the connotation expressed in British and American literature with the most objective statements, actions and thoughts. Specifically, cultural transfer situation should be set in British and American culture teaching in colleges and universities as far as possible, to analyze and compare the two languages and cultures contained in British and American literature works, establish a cultural function system of language learning from the aspects of phonology, grammar, vocabulary and article, guide students to read and write, help students to learn about the literature and culture connotations of Britain and America by means of music, movie, and special lecture on foreign literature knowledge, and lead students to discuss the similarities and differences of language structure and cultural connotation in literature works. Teachers also should actively make use of the positive transfer effect of the native language in teaching, to help students to learn about the cultural conventions, religious faith, historical facts and other aspects of Britain and America, and increase the likelihood of overcoming heterogeneous barriers in foreign language teaching.

Besides, teachers should collect and accumulate cultural background knowledge and social custom examples of Britain and America, deliver lectures based on the background knowledge, and explain the literary quotations and local conditions and customs in literature works, to let students learn extended knowledge beyond the textbook. Meanwhile, teachers can encourage and guide students to watch some original movies of Britain and America, and lead students to carry out some activities based on western festivals, so as to make them experience the living habit and etiquette of westerners, and help them to break through the heterogeneous barriers and develop cross-culture awareness. All these practices are helpful to English learning.

\section{2 (II) Establishment of Behavior System of Cross-culture Awareness of College Students}

The other teaching method for breaking through the heterogeneous barriers of British and American literature is to establish a behavior system for cross-culture awareness cultivation of college students, to enhance students' active learning ability through a more interactive teaching mode and build a student-centered autonomic learning-teaching mode.

In this paper, it is believed that colleges and universities who want to realize high-quality British and American literature teaching and achieve the purpose of cross-culture awareness cultivation should make greater efforts in textbook content arrangement, so as to stimulate students' learning interest while guaranteeing the interestingness of teaching content. If teaching objectives are set based on interest points of students, then students can overcome the heterogeneous barriers of British and American literature in a relaxing environment. To this end, a team-type learning mode should be designed to give more space to students, make students learn to think about and study cultural factors with the help of team, and promote students' interactivity and involvement of active learning. Take the example of the Role-play teaching mode. Teachers can simulate the context of situation for students based on British and American literature works, to let them realize the difference between British and American language and Chinese language, and know well about the intended connotation of British and American literature works. This is to establish a behavior system for students, to help them overcome the heterogeneous barriers and form cross-culture awareness.

In classroom learning about cross-cultural communication, teachers also can employ the annotation method and the explaining method to explain key events and key cultural settings in literature works, or intensify the intended connotation of Chinese and British and American culture contents, to diversify the teaching mode, and prevent students from feeling bored and flat when receiving heterogeneous culture[3].

\section{Summary}

Through understanding of heterogeneous barriers of British and American literature and exposition of methods of cross-culture awareness cultivation of college students, the importance of exchange between Chinese and Western cultures and literature works has been made clear in this paper. In the process of English teaching of college students, the heterogeneity and the identity between cultures 
and literatures must be balanced, and the two cultures must be treated equally in every aspect. Because this is helpful to broaden students' horizon, make them know better about British and American literature works, and really achieve the purpose of cross-culture awareness cultivation.

\section{References}

[1] Liu Caixia. Heterogeneous Barriers of British and American Literature and Cultivation of Cross-culture Awareness of College Students, Heilongjiang Researches on Higher Education, 2014,(2):140-142.

[2] Tang Yan. Cultivation of Cross-culture Awareness: Objectives of British and American Literature Curriculum, Heilongjiang Researches on Higher Education, 2010,(12):164-165.

[3] Niu Xiaowu. Problems in Cross-cultural Teaching of College English and Countermeasures, Testing and Evaluation, 2013,153-185. 